\title{
Screening, production and biochemical characterization of a new fibrinolytic enzyme produced by Streptomyces sp. (Streptomycetaceae) isolated from Amazonian lichens
}

\author{
Germana Michelle de Medeiros e SILVA ${ }^{1,2}$, Raquel Pedrosa BEZERRA33, José António TEIXEIRA 4 , \\ Flávio Oliveira SILVA ${ }^{3}$, Juliana Mendes CORREIA², Tatiana Souza PORTO5 ${ }^{5}$, José Luis LIMA-FILHO ${ }^{1,2,3}$, \\ Ana Lúcia Figueiredo PORTO ${ }^{1,2,3^{*}}$.

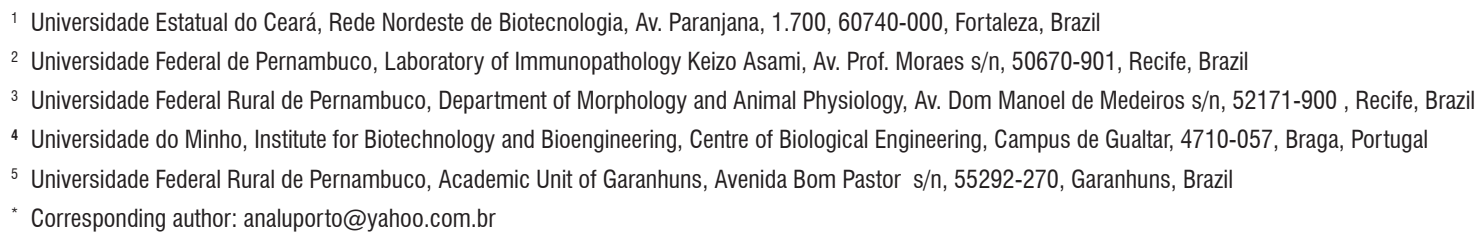

\section{ABSTRACT}

Thrombosis is a pathophysiological disorder caused by accumulation of fibrin in the blood. Fibrinolytic proteases with potent thrombolytic activity have been produced by diverse microbial sources. Considering the microbial biodiversity of the Amazon region, this study aimed at the screening, production and biochemical characterization of a fibrinolytic enzyme produced by Streptomyces sp. isolated from Amazonian lichens. The strain Streptomyces DPUA1576 showed the highest fibrinolytic activity, which was $283 \mathrm{~mm}^{2}$. Three variables at two levels were used to assess their effects on the fibrinolytic production. The parameters studied were agitation $(0.28-1.12 \mathrm{~g})$, temperature $\left(28-36^{\circ} \mathrm{C}\right)$ and $\mathrm{pH}(6.0-8.0)$; all of them had significant effects on the fibrinolytic production. The maximum fibrinolytic activity $\left(304 \mathrm{~mm}^{2}\right)$ was observed at $1.12 \mathrm{~g}, 28{ }^{\circ} \mathrm{C}$, and $\mathrm{pH}$ of 8.0. The crude extract of the fermentation broth was used to assess the biochemical properties of the enzyme. Protease and fibrinolytic activities were stable during $6 \mathrm{~h}$, at a $\mathrm{pH}$ ranging from 6.8 to 8.4 and 5.8 to 9.2 , respectively. Optimum temperature for protease activity ranged between 35 and $55^{\circ} \mathrm{C}$, while the highest fibrinolytic activity was observed at $45{ }^{\circ} \mathrm{C}$. Proteolytic activity was inhibited by $\mathrm{Cu}^{2+}$ and $\mathrm{Co}^{2+}$ ions, phenylmethylsulfonyl fluoride (PMSF) and pepstatin A, which suggests that the enzyme is a serine protease. Enzymatic extract cleaved fibrinogen at the subunits $A \alpha$-chain, $A \beta$-chain, and $\gamma$-chain. The results indicated that Streptomyces sp. DPUA 1576 produces enzymes with fibrinolytic and fibrinogenolytic activity, enzymes with an important application in the pharmaceutical industry.

KEYWORDS: Actinomycetes, fibrinolytic protease, inhibitor protease, fibrinogenolytic activity.

\section{Seleção, produção e caracterização bioquímica de uma nova enzima fibrinolítica produzida por Streptomyces sp. (Streptomycetaceae) isolada de liquens da Amazônia}

\section{RESUMO}

A trombose é uma doença patofisiológica causada pelo acúmulo de fibrina no sangue. Proteases fibrinolíticas com potente atividade trombolítica são produzidas por diversas fontes microbianas. Considerando a biodiversidade microbiana da região amazônica, o presente estudo teve como objetivo a seleção, produção e caracterização bioquímica da enzima fibrinolítica de Streptomyces sp. isolado de líquens da Amazônia. Streptomyces DPUA1576 foi a melhor produtora com atividade fibrinolítica de $283 \mathrm{~mm}^{2}$. Três variáveis em dois níveis foram utilizadas para determinar as variáveis mais relevantes na produção da enzima fibrinolítica (FA). Os parâmetros estudados foram agitaçáo $(0.28-1.12 g)$, temperatura $\left(28-36^{\circ} \mathrm{C}\right)$ e $\mathrm{pH}(6.0-8.0)$ e todos obtiveram efeitos significativos na produçáo fibrinolítica. A maior atividade fibrinolítica $\left(304 \mathrm{~mm}^{2}\right)$ foi obtida a $1.12 \mathrm{~g}, 28{ }^{\circ} \mathrm{C}$ e pH 8.0. O extrato bruto da fermentação foi usado para determinar as propriedades bioquímicas da enzima. Atividades proteásica e fibrinolítica foram estáveis durante 6 horas no intervalo de $\mathrm{pH}$ entre 6.8 - 8.4 e 5.8 - 9.2, respectivamente. Temperatura ótima para a atividade proteásica foi entre $35-55^{\circ} \mathrm{C}$, enquanto que para a atividade fibrinolítica foi de $45^{\circ} \mathrm{C}$. Atividade proteásica foi inibida por íons $\mathrm{Cu}^{2+} \mathrm{e} \mathrm{Co}^{2+}$, fluoreto de fenilmetilsulfonil e pepstatina $\mathrm{A}$, na qual sugere que a enzima é uma serino-protease. $\mathrm{O}$ extrato enzimático degradou o fibrinogênio nas subunidades $A \alpha, A \beta$ e $\gamma$. Os resultados apresentados indicam que Streptomyces sp. DPUA 1576 produz enzimas com atividade fibrinolítica e fibrinogenolítica, enzimas com aplicaçóes importantes na indústria farmacêutica.

PALAVRAS-CHAVE: Actinomycetos, protease fibrinolítica, inibidor de protease, atividade fibrinogenolítica 


\section{INTRODUCTION}

Thrombosis is one of the most widely occurring diseases in modern life. It occurs by the accumulation of fibrin when injury on tissue occurs. Normally, the fibrin formed in the blood is dissolved by the action of plasmin (E.C. 3.4.21.7). The unsolved clot by plasmin leads to the formation of thrombus, a serious problem because it induces cerebral and cardiovascular disease (Deepak et al. 2010). There are many drugs used on fibrinolytic therapy such as streptokinase (EC 3.2.1.35), staphylokinase (EC 3.4.21.35), urokinase (EC 3.4.21.31) but all of them have side effects. Thrombolytic therapy today is expensive and has undesirable side effects such as the risk for internal hemorrhage within the intestinal tract when orally administrated (Zhang et al. 2007).

Worldwide, over $29 \%$ of the total mortalities are due to thrombosis. By the year 2020, cardiovascular diseases (CVDs) may cause an estimated 25 million deaths per year, thus antithrombotic therapy is of great interest (Kotb 2014). Over the years, thrombolytic therapies via injecting or orally administrating thrombolytic agents to lyses thrombi in blood vessels have been extensively investigated (Peng et al. 2005). Therefore, continuous efforts have been focused in the search of safer and less expensive thrombolytic agents from diverse sources. Until recently, fibrinolytic enzyme with potential thrombolytic application has been purified from various sources such as fermented food, earthworms, mushrooms, snake venom and microbial sources (Kotb 2014). Microbial sources, such as bacteria, actinomycetes, fungi and algae are reported to produce fibrinolytic enzyme with few reports on the use of Streptomyces sp. (Chitte et al. 2011). Streptomyces sp. produces several extracellular enzymes of commercial interest, such as protease, pectinase, xylanase and cellulase. Proteases constitute two thirds of the total number of enzymes used in industry and this is expected to increase. Some of these proteases are fibrinolytic enzymes capable of digesting fibrin (Silva et al. 2015).

Considering the microbiological potential of the Amazon Region and the growing applicability of fibrinolytic proteases, the screening of Streptomyces sp. appears to be an interesting approach to finding novel fibrinolytic producers to reduce the drawbacks of marketed thrombolytic drugs. Therefore, this study aimed at the screening, production and biochemical characterization of a fibrinolytic enzyme produced by Streptomyces sp. isolated from Amazonian lichens.

\section{MATERIALS AND METHODS}

\section{Screening of isolates with fibrinolytic activity}

Fifty Streptomyces spp. isolates obtained from Amazonian lichens were used for fibrinolytic enzyme screening (Table 1). These Streptomyces isolates form part of the Culture Collection of the Parasitology Department of the Federal University of Amazonas (DPUA/UFAM-Brazil).

The inoculum was produced following the International Streptomyces Project medium 2 (ISP-2) broth in orbital shaker (BR-300LF, TAITEC Co, Tokyo, Japan), agitation of $1.12 \mathrm{~g}$ for $48 \mathrm{~h}$ at $28^{\circ} \mathrm{C}$. Enzyme production was carried out with initial cell concentration of $1 \times 10^{6}$ cells $\mathrm{mL}^{-1}\left(A_{600}=0.1\right)$ in 250-mL-Erlenmeyer flasks containing $50 \mathrm{~mL}$ of soybean flour medium (Porto et al. 1996), and incubated for $72 \mathrm{~h}$ at different conditions of agitation, temperature and $\mathrm{pH}$ as described in the Table 2. The samples were clarified by centrifugation (KR-20000T, Kubota, Osaka, Japan) at $8000 \mathrm{~g}$ and $4{ }^{\circ} \mathrm{C}$ for $10 \mathrm{~min}$, and submitted to fibrinolytic activity determination.

\section{Experimental design and statistical analysis}

To assess the protease and fibrinolytic activity, a factorial arrangement with two levels and three variables (agitation, temperature and $\mathrm{pH}$ ) was used to determine the most relevant combination. There were assessed agitation at 100, 150 and $200 \mathrm{rpm}$; these values corresponded to $g$ forces of $0.28,0.63$ and 1.12 , respectively. There were also evaluated temperature (ranged between $28-36^{\circ} \mathrm{C}$ ) and $\mathrm{pH}$, between 6 and 8 (Table $2)$. All statistical and graphical analyses were carried out with the Statistica 8.0 software (StatSoft Inc., Tulsa, OK, USA).

\section{Culture condition}

The best fibrinolytic enzyme-producing Streptomyces sp. was cultivated in ISP-2 under the production conditions described in the experimental design (Table 2) during $144 \mathrm{~h}$, in order to study cell growth, protease and fibrinolytic enzyme production. Cell concentration, $\mathrm{pH}$ and enzyme activity were analyzed every $12 \mathrm{~h}$.

\section{Effects of temperature and $\mathrm{pH}$ on protease and fibrinolytic activity}

The optimal temperature was determined by relative activity after incubating $60 \mu \mathrm{L}$ of crude extract and $100 \mu \mathrm{L}$ of azocasein $1 \%(\mathrm{w} / \mathrm{v})$ at different temperatures $\left(25-75^{\circ} \mathrm{C}\right)$ for 60 minutes. Thermal stability of crude extract was determined by measuring residual activity after incubating the enzyme for $120 \mathrm{~min}$ at the same range of temperatures, at $\mathrm{pH} 7.5$. The effects of $\mathrm{pH}$ on protease activity were assayed with azocasein $1 \%(\mathrm{w} / \mathrm{v})$ as substrate at various $\mathrm{pH}$ values $(4.0$ - 9.3) using standard buffers at $100 \mathrm{mM}$ : citric acid/sodium citrate $(4.0$ - 5.2); citric acid/sodium phosphate $(5.6-6.4)$, sodium phosphate $(6.8-7.2)$ Tris- $\mathrm{HCl}$ (7.6-9.4). To determine the $\mathrm{pH}$ stability of the enzyme, aliquots of enzyme samples were incubated with their respective buffers (mentioned above) for $120 \mathrm{~min}$ at $25^{\circ} \mathrm{C}$. The percentage of residual activity was calculated by considering the initial enzyme activity as $100 \%$. Each assay was carried out in triplicate. The effects of $\mathrm{pH}$ and temperature on fibrinolytic activity also were determined under the standard assay conditions described earlier. 
Table1. Screening of fibrinolytic activity obtained from different Streptomyces $\mathrm{sp}$.

\begin{tabular}{|c|c|c|c|}
\hline Sample & Halo $\left(\mathrm{mm}^{2}\right)$ & Sample & Halo $\left(\mathrm{mm}^{2}\right)$ \\
\hline Streptomyces sp. DPUA 1541 & 113 & Streptomyces sp. DPUA 1578 & 132.67 \\
\hline Streptomyces sp. DPUA 1543 & 50.24 & Streptomyces sp. DPUA 1579 & 143.07 \\
\hline Streptomyces sp. DPUA 1545 & 201 & Streptomyces sp. DPUA 1580 & 191.04 \\
\hline Streptomyces sp. DPUA1547 & 254 & Streptomyces sp. DPUA 1581 & 153.86 \\
\hline Streptomyces sp. DPUA 1549 & 78.50 & Streptomyces sp. DPUA 1582 & 132.67 \\
\hline Streptomyces sp. DPUA1550 & 254 & Streptomyces sp. DPUA 1583 & 7.07 \\
\hline Streptomyces sp. DPUA 1551 & 28.26 & Streptomyces sp. DPUA 1584 & 50.24 \\
\hline Streptomyces sp. DPUA 1553 & 78.50 & Streptomyces sp. DPUA 1586 & 200.96 \\
\hline Streptomyces sp. DPUA 1554 & 201 & Streptomyces sp. DPUA 1587 & 63.59 \\
\hline Streptomyces sp. DPUA 1557 & 0.79 & Streptomyces sp. DPUA 1589 & 153.86 \\
\hline Streptomyces sp. DPUA 1559 & 113 & Streptomyces sp. DPUA 1591 & 176.63 \\
\hline Streptomyces sp. DPUA 1560 & 113 & Streptomyces sp. DPUA 1595 & 19.63 \\
\hline Streptomyces sp. DPUA 1561 & 50.24 & Streptomyces sp. DPUA 1597 & 200.96 \\
\hline Streptomyces sp. DPUA 1563 & 133 & Streptomyces sp. DPUA 1598 & 132.67 \\
\hline Streptomyces sp. DPUA 1565 & 113 & Streptomyces sp. DPUA 1599 & 153.86 \\
\hline Streptomyces sp. DPUA 1566 & 154 & Streptomyces sp. DPUA 1600 & 113.04 \\
\hline Streptomyces sp. DPUA 1567 & 30.18 & Streptomyces sp. DPUA 1602 & 153.86 \\
\hline Streptomyces sp. DPUA 1568 & 154 & Streptomyces sp. DPUA 1603 & 200.96 \\
\hline Streptomyces sp. DPUA 1570 & 133 & Streptomyces sp. DPUA 1605 & 153.86 \\
\hline Streptomyces sp. DPUA 1571 & 0.00 & Streptomyces sp. DPUA 1606 & 254.34 \\
\hline Streptomyces sp. DPUA 1572 & 30.18 & Streptomyces sp. DPUA 1608 & 113.04 \\
\hline Streptomyces sp. DPUA 1573 & 189 & Streptomyces sp. DPUA 1609 & 113.04 \\
\hline Streptomyces sp. DPUA 1575 & 18.09 & Streptomyces sp. DPUA 1610 & 176.63 \\
\hline Streptomyces sp. DPUA 1576 & 283 & Streptomyces sp. DPUA 1611 & 113.04 \\
\hline Streptomyces sp. DPUA 1577 & 177 & Streptomyces sp. DPUA 1612 & 176.63 \\
\hline
\end{tabular}

\section{Effects of metal ions and inhibitors}

The enzyme extract can be classified by their sensitivity to various inhibitors for $30 \mathrm{~min}$ at room temperature and the residual activity was measured. Effect of metal ion $\mathrm{Zn}^{+2}, \mathrm{Na}^{+}, \mathrm{Mg}^{+2}, \mathrm{Fe}^{+2}, \mathrm{Cu}^{+2}, \mathrm{Ca}^{+2}, \mathrm{Mn}^{+2}, \mathrm{Co}^{+2}$ and inhibitors phenylmethylsulfonyl fluoride (PMSF), ethylenediaminetetraacetic (EDTA), Pepstatin A and iodoacetic acid were determined. The activity of the enzyme assayed in the absence of inhibitors was taken as 100\%. Each assay was carried out in triplicate.

\section{Protease activity determination}

Protease assay was conducted according to Alencar (2003). That is, a micro centrifuge tube was added of $100 \mu \mathrm{L}$ of $1 \%$ azocasein ( $\mathrm{w} / \mathrm{v}$, in $0.2 \mathrm{M}$ Tris- $\mathrm{HCl}, \mathrm{pH} 7.2$ ), and $60 \mu \mathrm{L}$ of crude extract. The reaction runs for $60 \mathrm{~min}$ at $25^{\circ} \mathrm{C}$. Then, $480 \mu \mathrm{L}$ of $10 \%(\mathrm{w} / \mathrm{v})$ trichloroacetic acid (TCA) were added to stop the reaction. After $15 \mathrm{~min}$, centrifugation was carried out for $5 \mathrm{~min}$ at $8000 \mathrm{~g}$. The supernatant $(320 \mu \mathrm{L})$ was added to $1 \mathrm{M} \mathrm{NaOH}(560 \mu \mathrm{L})$ and the absorbance of this mixture was measured at $440 \mathrm{~nm}$ (B582 spectrofotometer, Micronal,
São Paulo, Brazil) against a blank similarly prepared except that $0.15 \mathrm{M} \mathrm{NaCl}$ replaced the crude extract sample. One unit $(\mathrm{U})$ of enzymatic activity was defined as the amount of enzyme capable to produce a 0.001 change in absorbance per minute. The analysis was performed in triplicate. Protein content was determined by after Bradford (1976) using bovine serum albumin as standard.

\section{Fibrinolytic activity determination}

Fibrinolytic activity was determined using the fibrin plate method of Astrup and Mullertz (1952), with minor modifications, as follows. The fibrin agarose plate was made by $1 \%$ agarose, $0.1 \%$ human fibrinogen, and $8 \mathrm{U} \mathrm{mL}^{-1}$ of Human thrombin. The clot was allowed to stand for $1 \mathrm{~h}$ at room temperature. Then, $20 \mu \mathrm{L}$ of sample solution were placed onto the plate. The plate was incubated at $37^{\circ} \mathrm{C}$ for $18 \mathrm{~h}$ and the diameter of the lytic circle measured. In the fibrin plate method, a clear transparent region is observed in which fibrin is hydrolyzed, and its diameter is directly proportional to the intensity of the fibrinolytic activity. The lysed area was evaluated as the circle area (in square millimeter). Plasmin from human plasma was used as positive control. 
Table 2. Protease and fibrinolytic protease production by Streptomyces sp DPUA 1576 under the effect of agitation, temperature and pH treatments.

\begin{tabular}{lccccc}
\hline Runs & $\begin{array}{c}\text { Agitation } \\
(g)\end{array}$ & $\begin{array}{c}\text { Temperature } \\
\left({ }^{\circ} \mathrm{C}\right)\end{array}$ & $\mathrm{pH}$ & $\begin{array}{c}\mathrm{PA} \\
\left(\mathrm{U} \mathrm{mL}^{-1}\right)\end{array}$ & $\begin{array}{c}\mathrm{FA} \\
\left(\mathrm{mm}^{2}\right)\end{array}$ \\
\hline 1 & 0.28 & 28 & 6 & 1.76 & 0 \\
2 & 1.12 & 28 & 6 & 1.94 & 0 \\
3 & 0.28 & 36 & 6 & 1.94 & 0 \\
4 & 1.12 & 36 & 6 & 21.7 & 123 \\
5 & 0.28 & 28 & 8 & 20.9 & 13.6 \\
6 & 1.12 & 28 & 8 & 105 & 304 \\
7 & 0.28 & 36 & 8 & 7.41 & 0.35 \\
8 & 1.12 & 36 & 8 & 96.6 & 268 \\
9 & 0.63 & 32 & 7 & 3.43 & 0 \\
10 & 0.63 & 32 & 7 & 3.61 & 0 \\
11 & 0.63 & 32 & 7 & 2.13 & 0 \\
\hline
\end{tabular}

PA- Proteolytic activity, FA- Fibrinolytic activity.

\section{Sodium dodecyl sulfate polyacrylamide gel electrophoresis (SDS PAGE) of the crude extract and zymography}

The molecular weights of the proteins of crude extract were determined using SDS-PAGE (12\%) according to the method of Laemmli (1970). Electrophoresis was carried out at $20 \mathrm{~mA} / \mathrm{gel}$ in Tris-glycine buffer, $\mathrm{pH} 8.3$, containing $0.01 \%$ SDS. Zymography were performed with gelatin. Gelatin at $0.2 \%$ was copolymerized with $12 \%$ resolving gel. After electrophoresis, the gel was washed successively with Tris-HCL buffer ( $\mathrm{pH}$ 7.5) containing 2.5\% triton $\mathrm{X}-100$ and glycine- $\mathrm{NaOH}$ buffer $(\mathrm{pH}$ 9.0). The gel was then incubated in glycine- $\mathrm{NaOH}$ buffer overnight at $37^{\circ} \mathrm{C}$ and stained with coomassie brilliant blue R-250 for visualization of the clear zones. The molecular-weight standard proteins used were phosphorylase b $(97.4 \mathrm{kDa})$, albumin $(66.2 \mathrm{kDa})$, ovoalbumin $(45.0 \mathrm{kDa})$, carbonic anhydrase $(30.1 \mathrm{kDa})$, trypsin inhibitor $(20.5 \mathrm{kDa})$, and $\alpha$-lactalbumin $(14.4 \mathrm{kDa})$. The slab gels were stained with Coomassie Blue R-250, 0.25\% (w/v), in acetic acid : methanol : water $(1: 4.5: 4.5, \mathrm{v} / \mathrm{v})$. The molecular weight was estimated by LabImage 1D L340 program.

\section{Fibrinogenolytic activity determination}

Fibrinogenolytic activity was determined by modified fibrinogenolytic assay (Gao et al. 1998). The fibrinogen solution $(0.05 \mathrm{ml}$ of $2 \%$ human fibrinogen in $50 \mathrm{mM}$ Tris$\mathrm{HCl}$ buffer, $\mathrm{pH} 7.6,0.15 \mathrm{M} \mathrm{NaCl}$ ) was mixed with $300 \mu \mathrm{g}$ of crude extract and it was incubated at $37^{\circ} \mathrm{C}$ for $0,5,15,30$, $60 \mathrm{~min}$ and 5, 12, $24 \mathrm{~h}$. After the indicated time intervals, an aliquot of $0.05 \mathrm{ml}$ reaction mixture was transferred to $0.05 \mathrm{ml}$ denaturing reagent (10 M urea, 4\% SDS and 4\% 2 -mercaptoethanol) and incubated at $37^{\circ} \mathrm{C}$ for $24 \mathrm{~h}$. The sample was then analyzed by $12.5 \%(\mathrm{w} / \mathrm{v})$ SDS-PAGE.

\section{RESULTS}

\section{Screening of fibrinolytic activity, cell growth and protease production}

Screening on fibrin agar plates showed that forty-nine Streptomyces sp. isolates from Amazonian lichens were able to display extracellular fibrinolytic activity. Streptomyces DPUA1576 obtained the highest fibrinolytic activity of $283 \mathrm{~mm}^{2}$ (Table 1).

The relationship between protease activity and Streptomyces sp. DPUA 1576 growth is shown in Figure 1. Protease production started at the stationary growth phase at $72 \mathrm{~h}$ and remained constant up to $132 \mathrm{~h}$; then a linear decrease was observed. The highest extracellular protease activity of 11.5 $\mathrm{U} \mathrm{mL} \mathrm{L}^{-1}$ and fibrinolytic activity of $300 \mathrm{~mm}^{2}$ obtained after $72 \mathrm{~h}$ of fermentation. Maximum cell concentration was $4.5 \mathrm{~g}$ $\mathrm{L}^{-1}$ at $36 \mathrm{~h}$ of cultivation. The $\mathrm{pH}$ value decreased during cell growth until reaching stationary growth phase.

\section{Effects of agitation, $\mathrm{pH}$ and temperature on protease and fibrinolytic production by multi-factorial experiments}

The obtained values for protease and fibrinolytic activity for the different trials are shown in Table 2. Protease activity varied from 1.76 to $105 \mathrm{U} \mathrm{mL}^{-1}$ and fibrinolytic activity from 0 to 304 $\mathrm{mm}^{2}$ (Table 2). A first order (main effects) model was used to analyze the data from the factorial design. The main effects of the examined factors on the protease and fibrinolytic activities were calculated and are presented graphically in Figure 2A and $2 \mathrm{~B}$, respectively. Agitation, $\mathrm{pH}$, interaction between agitation and $\mathrm{pH}$, agitation and temperature had a positive effect $(p<$ $0.01)$ on protease production while the interaction between temperature and $\mathrm{pH}$ has a negative effect $(p<0.05$; Figure $2 \mathrm{~A})$. The main effect of temperature on protease production was not significant $(p>0.05)$ as shown on the Pareto chart (Figure 2A).

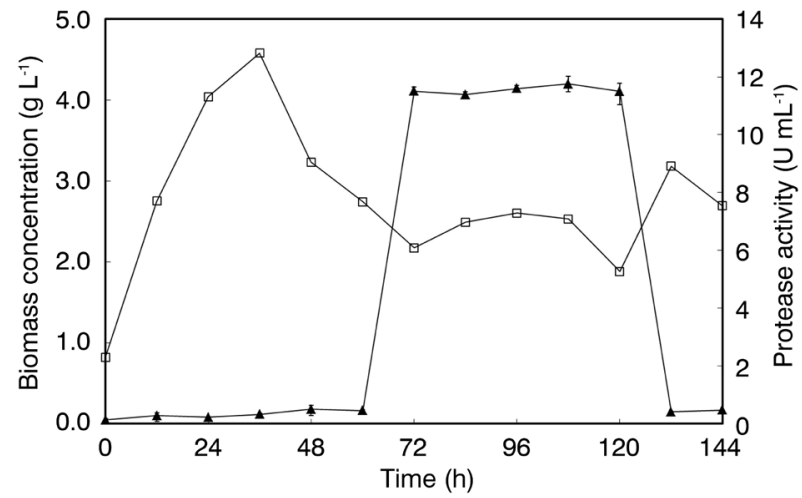

Figure 1. The time profile of cell growth of Streptomyces sp. DPUA 1576 and fibrinolytic activity during fermentation: (open square) Biomass $\left(\mathrm{g} \mathrm{L}^{-1}\right)$, (closed triangles) Protease activity $\left(\mathrm{U} \mathrm{mL}^{-1}\right)$; 
Regarding the fibrinolytic enzyme production, only the main effect of agitation was positive and significant $(p<0.05$, Figure 2B). As shown in Table 2, the increase in agitation of the flask shaker led to a remarkable enhancement of enzyme production and the highest enzyme activity was $304 \mathrm{~mm}^{2}$ at $1.12 \mathrm{~g}(200 \mathrm{rpm})$. The highest fibrinolytic activity $\left(304 \mathrm{~mm}^{2}\right)$ was obtained under initial culture $\mathrm{pH} 8.0$, agitation of 1.12 $g$ and temperature of $28^{\circ} \mathrm{C}$ (run 6; Table 2).

\section{Effects of temperature and $\mathrm{pH}$ on protease and fibrinolytic activity}

The protease was active at temperatures ranging from 25 to $55^{\circ} \mathrm{C}$ and had an optimum temperature between 35 to $55^{\circ} \mathrm{C}$, while the activity decreased at a temperature higher than $55^{\circ} \mathrm{C}$ (Figure 3). The relative activities at 25 and 75 ${ }^{\circ} \mathrm{C}$ were $59 \%$ and $49 \%$, respectively. Protease activity was stable during $120 \mathrm{~min}$ at 25 and $35^{\circ} \mathrm{C}$ and showed 98,100 , and $59 \%$ residual activity at 25,35 and $45^{\circ} \mathrm{C}$, respectively. The enzyme in the crude extract lost its activity after 60 min between 55 to $75^{\circ} \mathrm{C}$. The effect of temperature on the
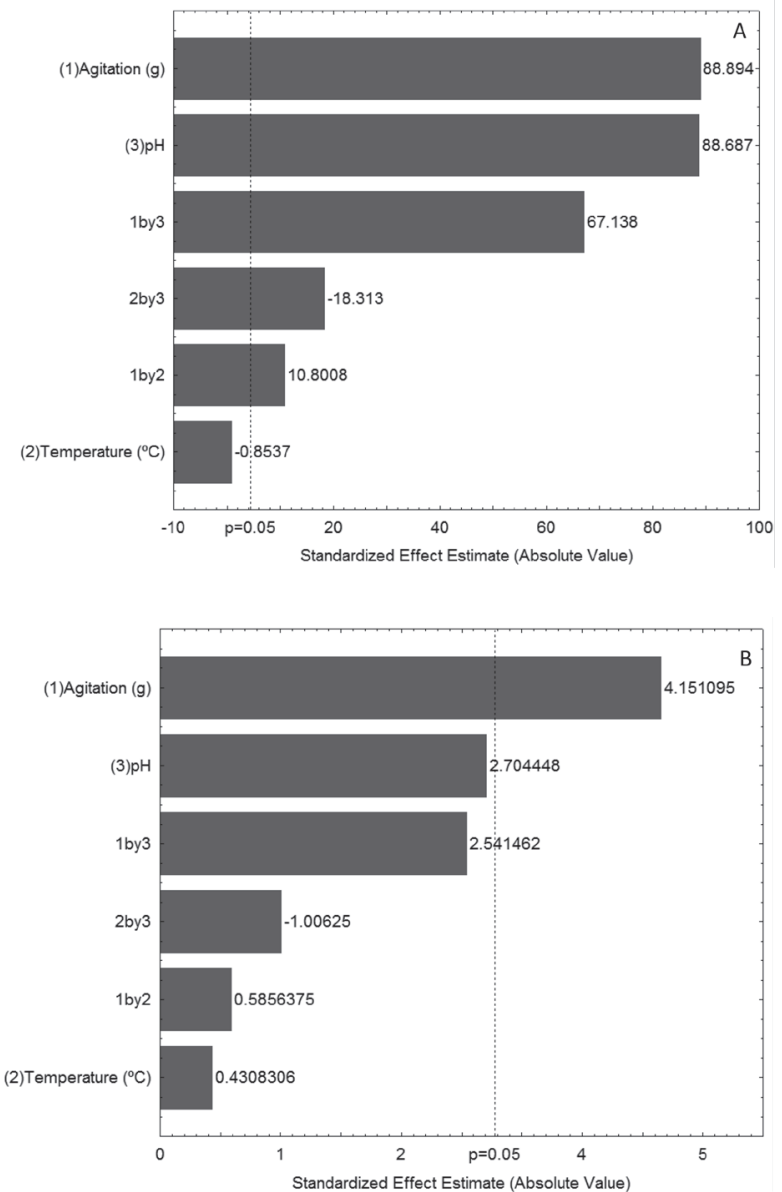

Figure 2. Pareto Chart showing variables and interactions on (A) protease and (B) fibrinolytic production by Streptomyces sp DPUA 1576. fibrinolytic activity was examined. The temperature showing the maximal enzyme activity was $45^{\circ} \mathrm{C}$ (Figure 3 ).

The $\mathrm{pH}$ between 4.0 to 9.2 has effect on the proteolytic activity. The highest proteolytic activities were obtained in the alkaline range and the protease was stable in the $\mathrm{pH}$ range from 6.5 to 9.2 during $120 \mathrm{~min}$ (Figure 4). The optimum $\mathrm{pH}$ for the fibrinolytic activity was 7.5 , and the enzyme activity decreased rapidly at levels below $\mathrm{pH} 7.0$ and above $\mathrm{pH}$ 8.0. The enzyme was stable between $\mathrm{pH} 6.0$ and 9.5 for $360 \mathrm{~min}$ and the stability enzymatic decreased below pH 5.5 (Figure 4).

\section{Effects of metal ions and inhibitors}

The effects of metal ions and inhibitors on protease activity were investigated after incubation of the protease with different metal ions and inhibitors for $1 \mathrm{~h}$ at $25^{\circ} \mathrm{C}$. The activity of protease was slightly enhanced by the presence of $\mathrm{Na}^{+}$ions.

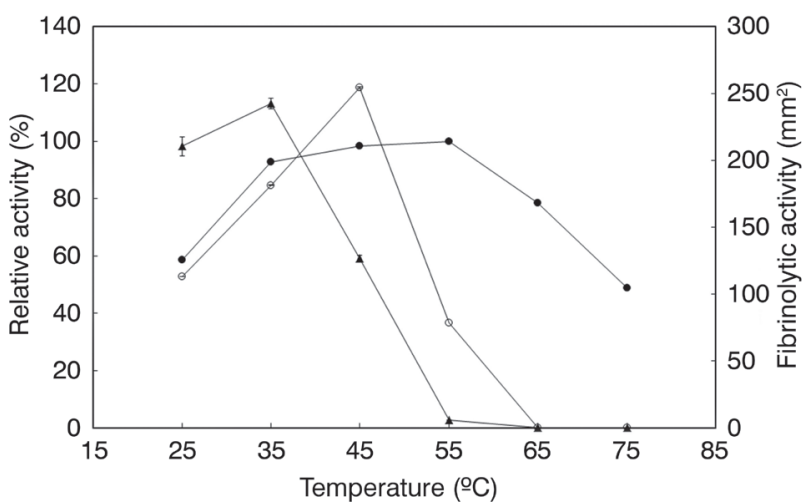

Figure 3. Effect of temperature on the proteolytic activity (closed circles), fibrinolytic activity (open circle) and proteolytic stability (closed triangles) from Streptomyces sp. DPUA1576. Optimum temperature of the enzyme was determined by assaying the activity at various temperatures. Thermal stability of the enzyme was determined by measuring the residual activity after the enzyme was incubated at selected temperatures for $6 \mathrm{~h}$.

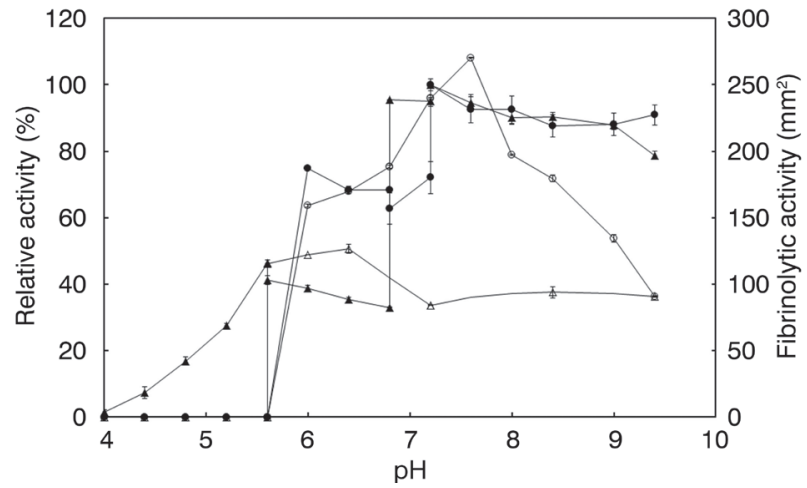

Figure 4. Effect of pH on protease activity (closed circles), Protease stability (closed triangles), fibrinolytic activity (open circles) and fibrinolytic stability (open triangles) from Streptomyces sp. DPUA1576. The determination of $\mathrm{pH}$ stability of the enzyme was measured by residual activity after the enzyme was incubated at the same $\mathrm{pH}$ ranges described above for $6 \mathrm{~h}$. 
On the other hand, the activity was significantly suppressed by $\mathrm{Cu}^{+2}$ and slightly inhibited by $\mathrm{Co}^{+2}$. No significant effects were observed by the presence of other metal ions on the protease activity (Table 3). Proteolytic activity was slightly inhibited by $1 \mathrm{mM}$ of EDTA and phenylmethylsulfonyl fluoride (PMSF), but significantly inhibited by $50 \mathrm{mM}$ of PMSF and $10 \mathrm{mM}$ of EDTA showing a residual activity of $25.4 \pm 0.30 \%$ and 39.9 $\pm 0.65 \%$, respectively. Pepstatin A at $1 \mathrm{mM}$ also inhibited the protease activity, resulting in a residual activity of $14.6 \pm 0.26 \%$ (Table 2). Inhibition profile showed in the Table 2 indicates that protease from Streptomyces sp. L5A35 is a serine protease.

\section{SDS-PAGE and fibrinogenolytic activity of crude fermentation extract}

SDS-PAGE analysis of the crude fermentation extract indicates the existence of several proteins in the range of 31 to $45 \mathrm{kDa}$ (line 2, Figure 5). A higher intensity band is observed at $39 \mathrm{kDa}$ suggesting that it corresponds to the fibrinolytic enzyme that correlated with the clear hydrolytic bands observed in the gelatin zymogram (line 3, Figure 5).

The fibrinogenolytic reaction of the extracellular protease produced from Streptomyces sp. DPUA1576 was analyzed with SDS-PAGE (Figure 6). In this case, the subunit chains of fibrinogen were completely hydrolyzed after $0.5 \mathrm{~h}$ of incubation.

Table 3. Effect of metal ions and protease inhibitors on proteolytic activity of Streptomyces sp. DPUA1576.

\begin{tabular}{|c|c|c|}
\hline Metal ion or inhibitor & Concentration (mM) & $\begin{array}{r}\text { Residual } \\
\text { activity \% }\end{array}$ \\
\hline None & 0 & $100 \pm 1.14$ \\
\hline $\mathrm{ZnSO}_{4}$ & 1 & $81.4 \pm 1.09$ \\
\hline $\mathrm{NaCl}$ & 1 & $106 \pm 0.26$ \\
\hline $\mathrm{MgSO}_{4}$ & 1 & $94.4 \pm 0.60$ \\
\hline $\mathrm{FeSO}_{4}$ & 1 & $95.3 \pm 2.14$ \\
\hline $\mathrm{CuSO}_{4}$ & 1 & $34.2 \pm 0.43$ \\
\hline $\mathrm{CaCl}_{2}$ & 1 & $88.8 \pm 1.67$ \\
\hline $\mathrm{MnCl}_{2}$ & 1 & $99.8 \pm 2.28$ \\
\hline $\mathrm{CoCl}_{2}$ & 1 & $60.8 \pm 2.68$ \\
\hline $\mathrm{FeCl}_{3}$ & 1 & $95.4 \pm 0.81$ \\
\hline Pepstatin A & 1 & $14.6 \pm 0.26$ \\
\hline \multirow[t]{3}{*}{$\begin{array}{l}\text { Phenylmethylsulfonyl fluoride } \\
\text { (PMSF) }\end{array}$} & 1 & $94.0 \pm 0.26$ \\
\hline & 10 & $91.4 \pm 0.31$ \\
\hline & 50 & $25.4 \pm 0.30$ \\
\hline \multirow[t]{2}{*}{ EDTA } & 1 & $71.8 \pm 0.52$ \\
\hline & 10 & $39.9 \pm 0.65$ \\
\hline \multirow[t]{2}{*}{ IODO } & 1 & $105.7 \pm 0.88$ \\
\hline & 10 & $100.1 \pm 0.50$ \\
\hline
\end{tabular}

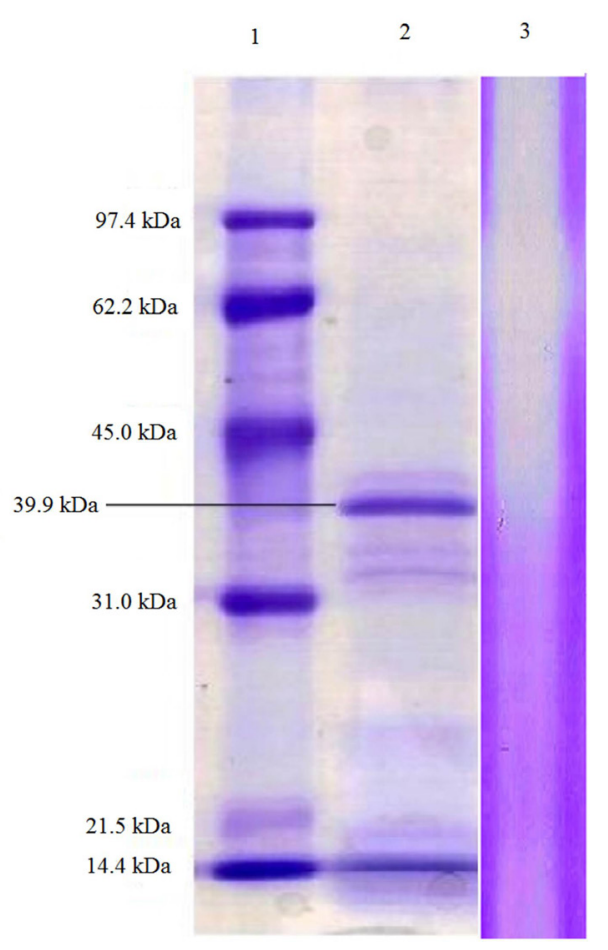

Figure 5. Electrophoresis SDS-PAGE of crude extract with fibrinolytic activity by Streptomyces sp. DPUA1576. $225 \mu \mathrm{g}$ of protein was loaded on a $12.5 \%$ acrylamide gel. Lane 1 shows the standard molecular weight; lane 2 shows the protein content of crude extract, lane 3 shows zymography.

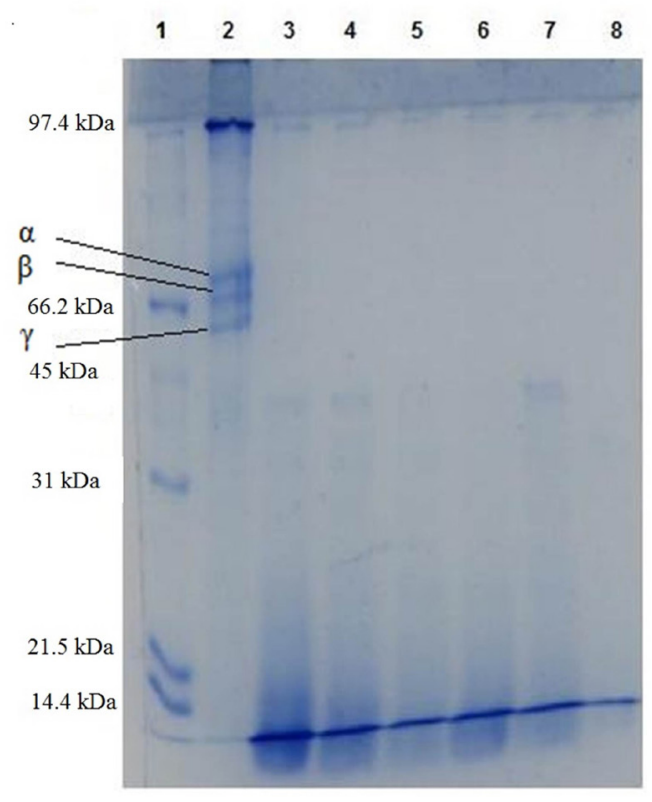

Figure 6. Hydrolysis of fibrinogen by Streptomyces sp. DPUA1576. (1) Fibrinogen $(40 \mu \mathrm{g})$ was incubated with fibrinolytic enzyme at $37^{\circ} \mathrm{C}$ for the various time intervals and analyzed by 12 (\%) SDS-PAGE. (2) Standard low molecular weight; (3) 0 (4) $0.5 \mathrm{~h} \mathrm{(5)} 1 \mathrm{~h} \mathrm{(6)} 2 \mathrm{~h}$ (7) 3h (8) 24h. 


\section{DISCUSSION}

Extracellular fibrinolytic activity showed that Streptomyces sp. isolated from Amazonian lichens presents clear haloes on fibrin plates indicating the ability of the produced enzymes to degrade fibrin in a direct way. Streptomyces DPUA1576 was selected as the best fibrinolytic producer $\left(283 \mathrm{~mm}^{2}\right)$ with enzyme activity higher than that obtained by Rovati et al. (2010) in fungal specimens isolated from the sub-tropical Las Yungas Pedemontana forest (Tucuman, Argentina). It reveals the potential of Streptomyces sp. strains from Amazonian lichens as an unconventional and unexplored production alternative to already known thrombolytic agents as well as a reservoir of microorganism species with promising biotechnological value could be also highlighted.

Streptomyces sp. DPUA 1576 showed maximum protease production after $72 \mathrm{~h}$ of incubation (stationary phase of cell growth) and the enzyme level declined with further incubation. Protease production during the stationary growth phase is in accordance with the studies of other authors (Miyaji et al. 2006; Gouda 2006). The protease production is directly related to biomass production (Gupta et al. 2002; Puri et al. 2002) and is associated with the stationary phase of cell growth (Puri et al. 2002; Rao 1998). The decline in protease production upon prolonged incubation may be due to autolysis or proteolytic activity of other proteases under starvation conditions (Puri et al. 2002).

At the growth stationary phase (Figure 1 ), the maximum proteolytic activity was observed after $72 \mathrm{~h}$, and its production was not growth-associated.

The $\mathrm{pH}$ value decreased during cell growth until reaching stationary growth phase, after remaining constant between 72 to $132 \mathrm{~h}$. The drop in $\mathrm{pH}$ may be attributed to the production of organic acids, which were consumed during later stages of growth resulting in a slight $\mathrm{pH}$ increase to 4.0 (Futamura et al. 2001). These results show that alkalinization of the medium is closely related with the degradation of extracellular proteins by proteases produced from Streptomyces sp DPUA1576, suggesting that alkalinization is adaptive. Our observations with Streptomyces sp. DPUA1576 suggest that this phenomenon may be widespread.

Temperature, agitation and $\mathrm{pH}$ are factors that influenced on protease and fibrinolytic productions. The decrease in the temperature caused an increase in protease production by Streptomyces sp DPUA1576. Other studies also showed that temperature is relevant factor for microbial protease production (Thys et al. 2006; Ellaiah et al. 2002) and an enhancement in protease production occurred when the temperature decreased from 50 to $25^{\circ} \mathrm{C}$ (Thys et al. 2006).

An increase in agitation of the flask shaker to $1.12 \mathrm{~g}$ (200 rpm) led to a remarkable enhancement of enzyme production. Streptomyces sp. is an aerophilic bacteria and increase the agitation providing a greater amount of oxygen for microorganism multiplication and metabolism. Al-Juamily and Al-Zaidy (2012) obtained a maximum fibrinolytic activity of $290 \mathrm{U}$, at $250 \mathrm{rpm}$.

The best $\mathrm{pH}$ for fibrinolytic enzyme production by Streptomyces sp DPUA 1576 was 8.0, similar to that reported by Bhavani et al. (2012) using Streptomyces venezuelae. The effect of $\mathrm{pH}$ is in agreement with previous reports on its effect on extracellular enzymatic activity (Caracuel et al. 2003).

In the initial culture, the highest fibrinolytic activity of $304 \mathrm{~mm}^{2}$ was obtained at $\mathrm{pH} 8.0$, agitation of $1.12 \mathrm{~g}(200$ $\mathrm{rpm}$ ) and temperature of $28{ }^{\circ} \mathrm{C}$. This result corresponds to a $41 \%$ increase in the enzyme activity, when compared to fibrinolytic activity of $215 \mathrm{~mm}^{2}$ using Bacillus licheniformis KJ-31 (Hwang et al. 2007). Silva et al. (2015) showed that Streptomyces sp. DPUA 1576 produced the highest fibrinolytic activity of $706.5 \mathrm{~mm}^{2}$ at $1.7 \%$ soybean flour and $1.0 \%$ glucose concentration, which was $33 \%$ higher than plasmin.

Optimum temperature for protease was between 35 to $55^{\circ} \mathrm{C}$ and to fibrinolytic was at $45^{\circ} \mathrm{C}$. Simkhada et al (2010) reported that the optimum temperature of fibrinolytic protease from Streptomyces sp CS684 was $45^{\circ} \mathrm{C}$, but it was not stable at this temperature, losing more than $50 \%$ of its activity after $90 \mathrm{~min}$. This enzyme was stable below $40{ }^{\circ} \mathrm{C}$.

The highest proteolytic activities were obtained in the alkaline range. Several other researchers have also described alkaline proteases with broad $\mathrm{pH}$ activities and stabilities. A purified alkaline protease from $B$. subtilis was observed to be stable with activity $\geq 78 \%$ in the $\mathrm{pH}$ range of 7.0-11.0, with the highest activity at pH 9.0 (Pandee et al. 2008)

The fibrinolytic enzyme was activated at neutral and alkaline $\mathrm{pH}$ values, and optimal reaction for fibrinolytic enzyme was obtained at $\mathrm{pH} 7.5$, which is similar to the optimum observed for Streptomyces sp. CS684 (Simkhada et al. 2010), but higher than Streptomyces sp. P3 (Cheng et al. 2015). The fibrinolytic enzyme from Streptomyces DPUA1576 was stable at $\mathrm{pH}$ 6.0-9.5, and the activity was greatly decreased below $\mathrm{pH}$ 6.0, exhibiting a $\mathrm{pH}$ stability comparably wider than that of Streptomyces sp. P3 (Cheng et al. 2015) and similar to Streptomyces sp. CS684 (Simkhada et al. 2010). These results suggest that the enzyme is active over a very narrow range of $\mathrm{pH}$ values, which indicates that FSP3 may be suitable for use in the human in vivo environment

The optimal temperature and $\mathrm{pH}$ value of fibrinolytic enzyme from Streptomyces sp. DPUA1576 were found to be $45^{\circ} \mathrm{C}$ and 7.5 , respectively. This values was similar to optimal temperature of $40{ }^{\circ} \mathrm{C}$ and $\mathrm{pH} 8.0$ obtained by Streptomyces venezuelae (Bhavani et al. 2012) and $50^{\circ} \mathrm{C}$ and $\mathrm{pH} 8.0$ obtained by Shewanella sp. IND20 (Vjayaraghavan and Vincent 2015). 
Proteolytic activity significantly was inhibited by PMSF, an inhibitor of serine proteases, which indicates that the enzyme's catalytic site includes a serine residue. These results are in agreement with (Afifah et al. 2014; Mukherjee and Rai 2011).

SDS-PAGE of crude fermentation extract indicates the highest intensity band at $39 \mathrm{kDa}$ suggesting it corresponds to the fibrinolytic enzyme, which is similar to that of fibrinolytic enzyme from Streptomyces megaspores SD5 (Chitte and Dey 2000) and Streptomyces sp. CS684 (Simkhada et al. 2010).

Another important activity of the fibrinolytic enzyme is its fibrinogenolytic reaction, by which fibrinogen is degraded. Extracellular protease produced from Streptomyces sp. DPUA1576 hydrolyzed completely fibrinogen after 0.5 $\mathrm{h}$ of incubation. This fibrinogenolytic pattern is completely different from the one obtained with the enzyme produced by Streptomyces sp. CS684, where degraded B $\beta$-chains and slowly released $\gamma$-chains and the Aa-subunit of fibrinogen remained resistant to degradation (Simkhada et al. 2010) and by Streptomyces omiyaensis which degraded the $\mathrm{A} \alpha$ and $\mathrm{B} \beta$ chains and $\gamma$ chains after 3 h of incubation (Uesugi et al. 2011).

\section{CONCLUSIONS}

Streptomyces sp. DPUA 1576 is a highly promising strain to be used in the production of fibrinolytic enzyme with a maximal enzyme activity of about $304 \mathrm{~mm}^{2}$ and may be a potential source of new and unexploited fibrinolytic enzymes for different therapeutic purposes. It was also demonstrated that the protease present in the medium broth could act both on fibrinogen and fibrin blocking the activation process of fibrinogen to fibrin.

The obtained results demonstrate that microbial enzymes have the potential to be developed as drugs to prevent or cure cardiovascular diseases, as fibrinolytic enzymes in the treatment of thrombosis.

\section{ACKNOWLEDGMENTS}

The authors grateful acknowledge the financial support of Fundação de Amparo a Pesquisa do Estado de Pernambuco (FACEPE, Pernambuco, Brazil, N. 0158-2.12/11), CNPq/ RENORBIO (National Counsel of Technological and Scientific Development, N.55146/2010-3) and National Council for the Improvement of Higher Education (CAPES, Brazil) for the scholarship. The author thanks editor and reviewers for their review and comments.

\section{REFERENCES}

Afifah, D.N.; Sulchan, M.; Syah, D.; Yanti, Suhartono, M.T.; Kim, J.H. 2014. Purification and characterization of a fibrinolytic enzyme from Bacillus pumilus 2.g isolated from Gembus, an
Indonesian fermented food. Preventive Nutrition and Food Science, 19: 213-219.

Alencar, R.B.; Biondi, M.M.; Paiva, P.M.G.; Vieira, V.L.A.; Carvalho, L.B.; Bezerra, R.S. 2003. Alkaline proteases from digestive tract of four tropical fishes. Brazilian Journal Food Technology, 6: $279-284$

Al-Juamily, E.; Al-Zaidy, B.H. 2012. Optimization conditions of production fibrinolytic enzyme from Bacillus lichniformis B4 local isolate. British Journal of Pharmacology and Toxicology, 3: 289-295.

Astrup, T.; Müllertz, S. 1952. The fibrin plate method for estimating fibrinolytic activity. Archives of Biochemistry and Biophysics, 40: 346-351.

Bhavani, B.; Naveena, B.; Partha, N. 2012. Strain improvement of Streptomyces venezuelae for enhanced fibrinolytic enzyme production. Advanced Materials Research, 584: 440-444.

Bradford, M.M. 1976. A dye binding assay for protein. Analytical Biochemistry, 72: 248-254.

Caracuel, Z.; Roncero, I.G.; Espeso, E.A.; González-Verdejo, C.I.; García-Maceira, F.I.; Di Pietro A. 2003. The pH signalling transcription factor PacC controls virulence in the plant pathogen Fusarium oxysporum. Molecular Microbiology, 48: 765-779.

Cheng, G.; He, L.; Sun, Z.; Cui, Z.; Du, Y.; Kong, Y. 2015. Purification and biochemical characterization of a novel fibrinolytic enzyme from Streptomyces sp. P3. Journal of Microbiology and Biotechnology, 25: 1449-1459.

Chitte, R.R.; Dey, S. 2000. Potent fibrinolytic enzyme from a thermophilic Streptomyces megaspores strain SD5. Letters Applied of Microbiology, 31: 405-110.

Chitte, R.R.; Deshmukh, S.V.; Kanekar, P.P. 2011. Production, purification, and biochemical characterization of a fibrinolytic enzyme from thermophilic Streptomyces sp. MCMB-379. Applied Biochemistry and Biotechnology, 165: 1406-1413.

Deepak, V.; Ilanvan, S.; Sampathkumar, M.V.; Victoria, M.J.; Pasha, S.P.B.S.; Pandian, S.B.R.K.; Gurunathan, S. 2010. Medium optimization and immobilization of purified fibrinolytic URAK from Bacillus cereus NK1 on PHB nanoparticles. Enzyme Microbiology and Technology, 47: 297-304.

Ellaiah, P.; Srinivasulu, B.; Adinarayana, K. 2002. A review on microbial alkaline proteases. Journal of Scientific and Industrial Research, 61: 690-704

Futamura, T.; Ishihara, H.; Tamura, T.; Yasutake, T.; Huang, G.; Kojima, M.; Okabe, M. 2001. Kojic acid production in an airlift bioreactor using partially hydrolyzed raw corn starch. Journal of Bioscience and Bioengineering, 92: 360-365.

Gao, R.; Zhang, Y.; Meng, Q.X.; Lee, W.H.; Li, D.S.; Xiong, Y.L.; Wang, W.Y. 1998 Characterization of three fibrinogenolytic enzymes from Chinese green tree viper (Trimeresurus stejnegeri) venom. Toxicon, 36: 457-467.

Gouda, M.K. 2006. Optimization and purification of alkaline proteases produced by marine Bacillus sp. MIG newly isolated from eastern harbour of Alexandria, Polish. Journal of Microbiology, 55: 19-126. 
Gupta, R.; Beg, Q.; Lorenz, P. 2002. Bacterial alkaline proteases: molecular approaches and industrial applications. Applied Microbiology and Biotechnology, 59: 15-32.

Hwang, J.K.; Choi, K.H.; Kim, M.J.; Park, C.S.; Cha, J. 2007. Purification and characterization of a new fibrinolytic enzyme of Bacillus licheniformis KJ-31, isolated from korean traditional jeotgal. Journal of Microbiology and Biotechnology, 17: 1469-1476

Kotb, E. 2014. The biotechnological potential of fibrinolytic enzymes in the dissolution of endogenous blood thrombi. Biotechnology Progress, 30: 656-672.

Laemmli, U.K. 1970. Cleavage of structural proteins during the assembly of the head of bacteriophage T4. Nature, 227: 680-685.

Miyaji, T.; Otta, Y.; Nakagawa, T.; Watanabe, T.; Niimura, Y.; Tomizuka, N. 2006 Purification and molecular characterization of subtilisin like alkaline protease. Letters in Applied Microbiology, 42: 242-247.

Mukherjee, A.K.; Rai, S.K. 2011. A statistical approach for the enhanced production of alkaline protease showing fibrinolytic activity from a newly isolated Gram-negative Bacillus sp. strain AS-S20-I. New Biotechnology, 28: 182-189.

Pandee, P.; H-Kittikul, A.; Masahiro, O.; Dissara, Y. 2008. Production and properties of a fibrinolytic enzyme by Schizophyllum commune BL23 Songklanakarin. Journal of Science and Technology, 30: 447-453.

Peng, Y.; Xiaojuan, Y.; Yizheng, Z. 2005. Microbial fibrinolytic enzymes: an overview of source, production, properties, and thrombolytic activity in vivo. Applied Microbiology and Biotechnology, 69: 126-132.

Porto, A.L.F.; Campos-Takaki, G.M.; Lima-Filho, J.L. 1996. Effects of cultural conditions on protease production by Streptomyces clavuligerus. Applied Biochemistry and Biotechnology, 60: 115-121.

Puri, S.; Beg, Q.K.; Gupta, R.G. 2002. Optimization of alkaline protease production from Bacillus sp. using response surface methodology. Current Microbiology, 44: 286-290.
Rao, M.B.; Tanksale, A.M.; Ghatge, M.S.; Deshpande, V.V. 1998. Molecular and biotechnological aspects of microbial proteases. Microbiology and Molecular Biology Reviews, 62: 597-635.

Rovati, J.I.; Delgado, O.D.; Figueroa, I.L.C.; Farina, J.I. 2010. A novel source of fibrinolytic activity: Bionectria sp., an unconventional enzyme-producing fungus isolated form Yungas rainforest (Tucumán, Argentina). World Journal Microbiology and Biotechnology, 26: 55-62.

Silva, G.M.M.; Bezerra, R.P.; Teixeira, J.A.; Porto, T.S.; Lima-Silva, J.L.; Porto, A.L.F. 2015. Fibrinolytic protease production by new Streptomyces sp. DPUA 1576 from Amazon lichens. Electronic Journal of Biotechnology, 18: 16-19.

Simkhada, J.R.; Mander, P.; Cho, S.S.; Yoo, J.C. 2010. A novel fibrinolytic protease from Streptomyces sp. CS684. Process Biochemistry, 45: 88-93.

Thys, R.C.S.; Guzzon, S.O.; Cladera-Olivera, F.; Brandelli, A. 2006. Optimization of protease production by Microbacterium sp. in feather meal using response surface methodology. Process Biochemistry, 42: 67-73.

Uesugi, Y.; Usuki, H.; Iwabuchi, M.; Hatanaka, T. 2011. Highly potent fibrinolytic serine protease from Streptomyces. Enzyme Microbiology and Technology, 48: 7-12.

Vjayaraghavan, P.; Vincent, S.G.P. 2015. A low cost fermentation medium for potential fibrinolytic enzyme production by a newly isolated marine bacterium, Shewanella sp. IND20. Biotechnology Reports, 7: 135-142.

Zhang, L.; Zhang, Z.G.; Liu, X.S.; Solgot, A.; Chopp, M. 2007. The PI3K/Akt Pathway Mediates the Neuroprotective Effect of Atorvastatin in Extending Thrombolytic Therapy After Embolic Stroke in the Rat. Arteriosclerosis, Thrombosis and Vascular Biology, 27: 2470-2475.

Recebido em 08/01/2016

Aceito em 16/02/2016 
